\title{
Ancient Rivers
}

\section{of the Eastern Egyptian Desert}

\author{
by Bahay Issawi
}

\begin{abstract}
The Nile is one of the world's most important and fascinating rivers, not least because it flows for most of its length through desert, the eastern Sahara. Radar images from space have demonstrated the presence of innumerable dry channelways beneath the Saharan sand, indicating a very different drainage pattern during the Tertiary and Quaternary. In this article the author reviews current ideas on the ancient drainage patterns in eastern Egypt, describing several river systems which crossed the desert in the Neogene and early Quaternary before the present Nile forced its way northwards.
\end{abstract}

\section{Early Investigations of the Nile Valley}

Recent systematic mapping of the deserts of Egypt and the Nile Valley has led to many discoveries which have important implications for our understanding of the Neogene and Quaternary. Apart from the pioneering work of Sandford and Arkell (1939), Caton-Thompson and Gardner (1932) on Kharga Oasis, and Huzayyin (1941) on the Nile basin, earlier workers paid little attention to the surficial deposits of Egypt. However, prompted by the building of the Aswan High Dam, Unesco has in the last three decades sponsored many studies of the anthropology and archaeology of the areas to be flooded. The findings of scholars from different parts of the world have resulted in the establishment of a tentative chronology of Quaternary events in the Nubia region during this time. Important discoveries on the Quaternary geology in south Egypt are revealed in the publications of Wendorf (1968), Wendorf and Schild (1976), Butzer and Hansen (1968), Said et al. (1970), Issawi et al. (1978) and Said (1981).

The southern Western Desert of Egypt has also attracted the attention of many workers, and a great wealth of information is found in the works of Haynes (in Wendorf and Schild, 1980) Haynes et al. (1979), Issawl (1978), Schild and Wendorf (1977; 1981), Wendorf (1968) and Wendorf and Schild (1976; 1980). These and other workers have mapped in detail both sides of the Nile Valley and many parts of the Western Desert where formerly the deposits had been given only the vague label 'Quaternary'.

The impact of these studies on the understanding of the Nile Valley and their bearing on the origin of the Nile itself was summarized recently in Said's book (1981) on the geological evolution of the Nile. The present paper elaborates on this work and presents a rather different view of the rivers that once flowed over the eastern part of Egypt.

\section{The Nile Valley in Egypt}

The Nile in Egypt flows from south to north for approximately $1000 \mathrm{~km}$. The river is surrounded by desert and during its course in Egypt it receives no water except during very rare cloudbursts. Both sides of its valley are covered by fertile silt which is extensively cultivated for a width of a few hundred meters to more than $20 \mathrm{~km}$ at Beni Suef, $120 \mathrm{~km}$ south of Cairo (Fig. 1).

Geological investigations in Nubia by de Heinzelin (in Wendorf, 1968, p.19-55), Butzer and Hansen (1968) and others indicate that the modern regime of the Nile River, with a stream flow largely dependent on rainfall over the Ethiopian highland, may well be a comparatively recent phenomenon, perhaps of Late Pleistocene age. Prior to that time, the Nile occupied its present valley north of the Second Cataract but appears to have been totally dependent upon non-Ethiopian sources. This stream is called either the Egyptian Nile or the

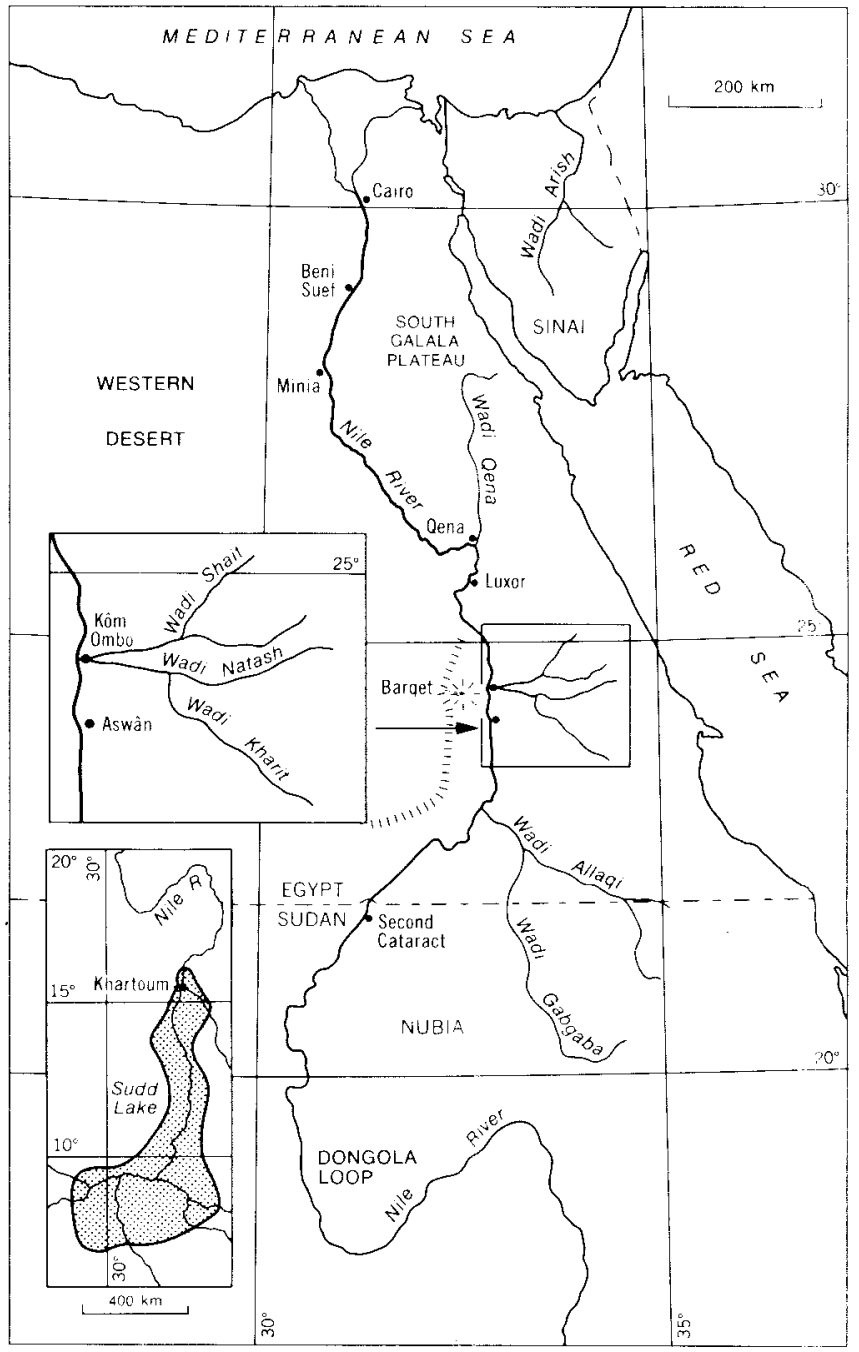

Figure 1: Location map of the Nile Valley showing important locations mentioned in the text. Inset shows extent of Sudd Lake in central Sudan. 
Pre-Nile to distinguish it from the modern river. Wendorf and Schild (1976) have, however, argued that the Ethiopian Nile is slightly older, dating back at least to the late Acheulean (ca. 150000 B.P.).

The stratigraphy of the Nile section is varied and complex (Said, 1981), and some areas, such as Nubia, south Aswan and Kom Ombo, expose considerable thickness of river sediments. In the Kom Ombo area, the basal sediments above the Upper Cretaceous are fluviatile sands with an age more than 41900 B.P. (Wendorf and Schild, 1976). The alignment of these sands along east-west channels indicates that the river depositing these sands flowed in the same direction and acquired its water and sediments from the high hills of the Red Sea. These hills were then, as at present, partly covered by Palaeozoic and younger sandstones (Issawi and Jux, 1982) which were the parent rocks for the basal sands at Kom Ombo. The next phase of river sediments here is represented by a $10 \mathrm{~m}$ thick sheet of conglomerate (Fig. 2) with a similar east-west trend. This is a wash deposit consisting mostly of igneous and metamorphic gravels deposited by a vigorous river which eroded the basement massifs of the Red Sea hills after the removal of their sandstone cap.

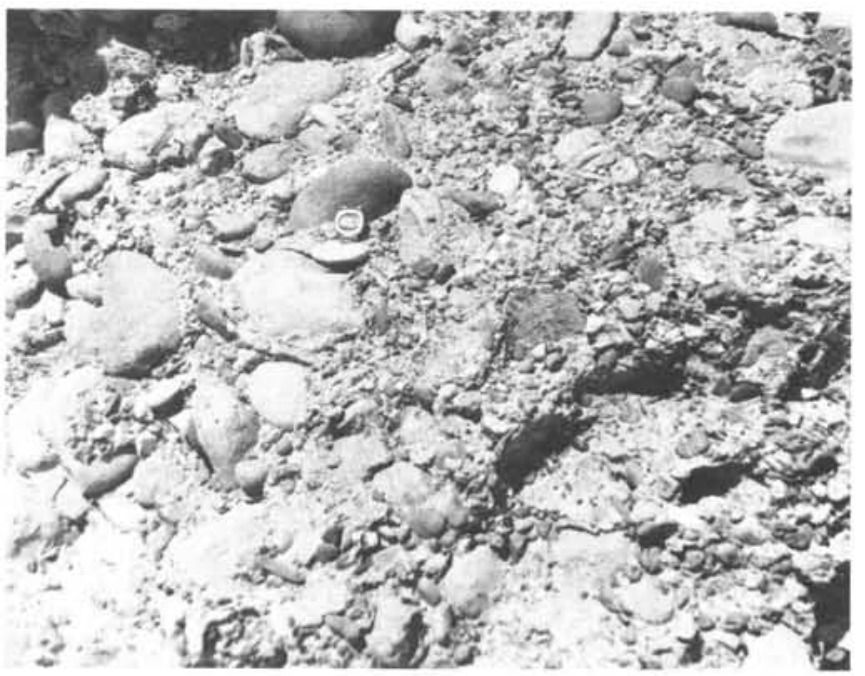

Figure 2: Kom Ombo conglomerate near the Wadi Qena fan.

Similar conditions were repeated further north. West of Luxor, Qena, Minia and Beni Suef, sands overlain by conglomerate wasn distinguish the base of the riverine section, extending to both sides of the present Nile. Apparently there were several rivers flowing from the east to the west prior to the onset of the present south-north river, which incised its channel through these older sediments.

Two phases of aggradation alternating with two of degradation distinguish the history of the Nile since its incision through the pre-Nile sediments (Table 1). The aggradational phases indicate substantial additions of Ethiopian and equatorial waters while the degradation episodes reflect the dominance of Egyptian rainfall and wadi wash activity. The composite section shown in Table 1 is repeated in part or entirely all along the Nile Valley.

The most intriguing part of the section is the Pre-Nile history where a mixture of old sediments, including rolled Acheulean and Mousterian (ca. 100000 B.P.) artifacts (Hassan et al. 1978), lie in juxtaposition with the present Nile sediments and indicate a significant period of deflation. However it becomes evident from the studies on the Nile Valley sections that two riverine systems contributed completely independently of each other to the sediments occupying the depression formed amid the Egyptian desert. The first of these systems drained the highlands along the Red Sea coast,

Table 1: Sediments of the Nile (from Butzer and Hansen, 1968; Wendorf and Schild, 1976 and Issawi et al., 1978).

Deposits

Shaturma Formation 2nd Nile degradation (wadi alluvium)

Sahaba Formation

(silt and sand)

Ineiba Formation

(wadi wash, sand

and gravels)

(Nile silt with

dune sands)

Kom Ombo Gravels and Qena Sands

\section{Riverine Phase}

2nd Nile aggradation

Ist Nile degradation

1st Nile aggradation
Masmas Formation

17450 B.P. \pm 300 years.

$17000-18000$ B.P.

whereas the second system (the present Nile) is totally dependent on water sources in Ethiopia or central Africa (Lake Victoria region).

Recent mapping of the Egyptian deserts has revealed vestiges of many old rivers in the huge dry valleys crossing the deserts. Although the history of these Pre-Nile rivers is not always clear and their age is very difficult to define, it is possible to show how the more important ones contributed to the building of the present Nile Valley.

\section{The Qena River}

Wadi Qena is a wide valley extending southwards for some $170 \mathrm{~km}$ from the South Galala Plateau to its broad fanning delta located on the Nile Valley plain east of Qena town (Fig. 3). This is one of three major wadis in Egypt, EI Arish in Sinai and Allaqi in southeastern Egypt being the other two. In some places Wadi Qena may have a width of $30 \mathrm{~km}$, in others it narrows to less than $5 \mathrm{~km}$. The wadi collects its water from the high cliffs of the Galala, the Eocene plateau to the west and the serrated metamorphic and igneous mountains to the east.

The wadi is characterized by many ridges and high terraces with their longer axes parallel to the main course. These features represent several stages in the downcutting of the wadi. They are mostly covered by fine silt and capped by dark desert-varnished gravels, which form an armoured surface protecting the easily deflated silt. The fluviatile sequence exposed in these terraces varies in thickness from a few meters to more than $50 \mathrm{~m}$. Acheulean hand axes are

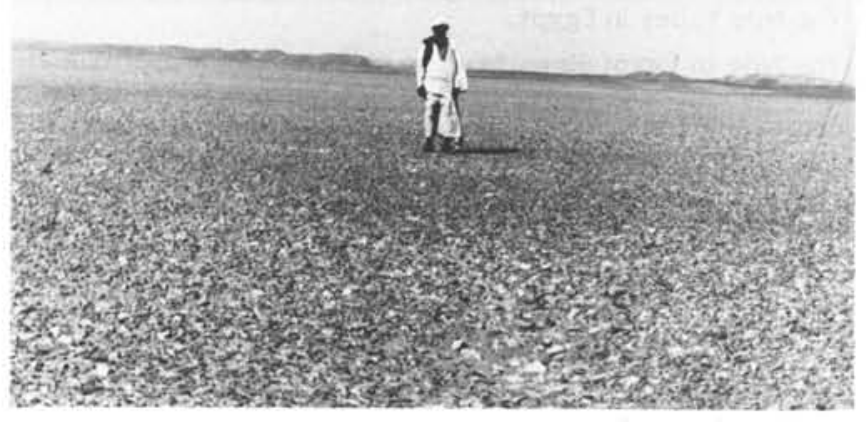

Figure 3: Wadi Qena delta, east of Qena town. 
common among the cap gravels and are probably the oldest artifacts in Egypt (F. Wendorf, personal communication).

Wadi Qena slopes gently to the south. A measure of the large sediment load carried by the Qena River during its active history is given by the size of its delta $\left(600 \mathrm{~km}^{2}\right)$, which may have extended also to the silt deposits west of the Nile here.

Although the terraces, the type of sediments in the wadi and the delta on both sides of the present Nile need further study, it appears that the opening of the wadi began in the Early Miocene, associated with the Red Sea tectonic history. It is clear, however, that whatever its origin a river of great magnitude once flowed southwards in this wadi, in opposition to the present Nile, which runs nearly perpendicular to the course of the old Qena River.

\section{The Allaqi River}

Wadi Allaqi located in the south Eastern Desert, and Wadi Gabgaba, its southern tributary, form a natural geological boundary (as does Wadi Qena) between the basement igneous and metamorphic complex to the east and the sedimentary Palaeozoic-Cretaceous sandstones to the west. The upstream tributaries of Wadi Allaqi to the east get their water nearly $300 \mathrm{~km}$ inside the desert before the wadi heads northwest to the Nile. Wadi Gabgaba collects its water more than $350 \mathrm{~km}$ inside Sudan and before the spectacular Dongola loop of the River Nile. Indeed it is still unknown why the Nile, instead of heading north through Gabgaba and Allaqi to Aswan, chose the more difficult route through the acute loop at Dongola and the many cataracts in its present channel.

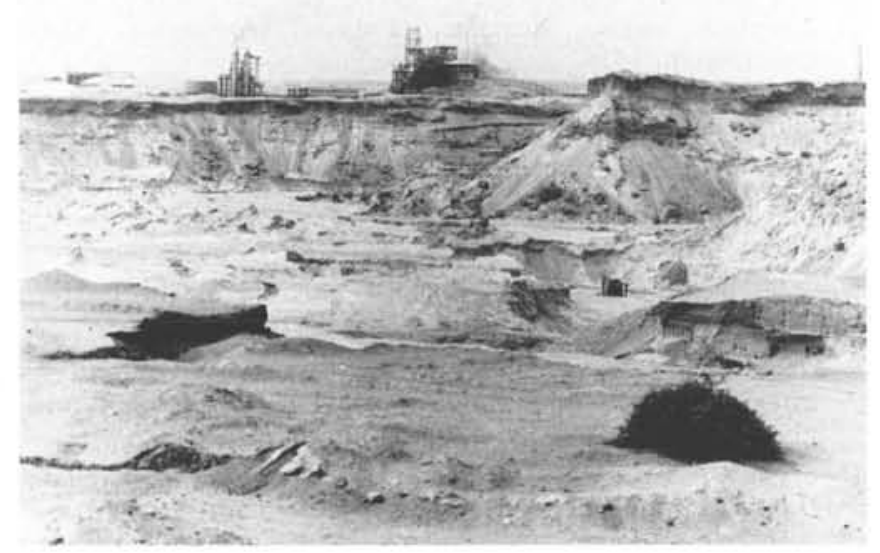

Figure 4: Sediments of the Allaqi River, east of Aswan. Thickness about $100 \mathrm{~m}$, mainly silt and fine sand.

The Allaqi River probably detoured east of the cataract at Aswan before fanning in the west side of the present river at the foot of the impressive Barqat Kom Ombo scarp (Issawi and Hinnawi, 1980). The thick (>100 m) silt and sand deposits just southeast of Aswan (Fig. 4) and on the plain west of the Nile opposite Kom Ombo, are certainly deposits of the Allaqi River. They appear to be Early Pliocene or even older, since marine Pliocene deposits near Aswan (Chumakov, 1967) cut through them. The Allaqi River could have thus flowed even further, filling the trench now occupied by the Nile Valley.

\section{The Kharit, Natash and Shait Rivers}

The Red Sea hills between latitudes $23^{\circ}$ and $25^{\circ}$ north are drained by Wadis Kharit, Shait and Natash. Shait extends to the SW for $120 \mathrm{~km}$, Kharit to the NW for $160 \mathrm{~km}$ and Natash to the west for $140 \mathrm{~km}$. The Kharit, Shait and Natash Rivers are probably Pliocene to Quaternary in age.

The three wadis join together forming a major channel just east of the Nile on the Kom Ombo plain, and a huge delta extends to the east and west of the present Nile. West of the
Nile the fan of these wadis and their sediments (the Qena Sands and the Kom Ombo gravels of Issawi and Hinnawi, 1980) coalesce with the fan deposits of River Allaqi at Barqat Kom Ombo to form a huge patch of deltaic deposit of which only a remnant, nearly $150 \mathrm{~km}^{2}$ in area, remains (Fig. 5). The Nile has cut its present south-north channel through these deposits, again nearly perpendicular to the trend of the old channel.

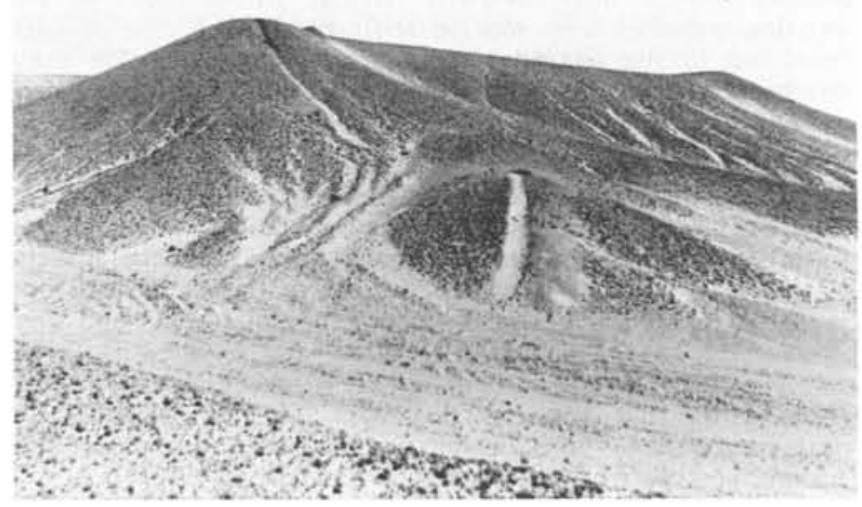

Figure 5: Gravel terraces near the fan of the Allaqi River, west of Kom Ombo area. Exposure $100 \mathrm{~m}$ high.

\section{An Evolving Landscape}

Between the Late Miocene and the Middle Quaternary, several distinct river systems flowed over the surface of eastern Egypt, fed mainly by run-off from the Red Sea hills. It was not until later that waters from Ethiopia and central Africa found their way to Egypt, cutting the present Nile channel and contributing to its valley sediments. Adamson (1982) believes that the Nile has supplied water from Ethiopia to the Mediterranean since the Tertiary. However, our work in Egypt does not support this view (see Said, 1981).

There is no doubt that the trench occupied by the present Nile was at least in part structurally controlled (Youssef, 1968). Scarps on both sides of the Nile retreated along nor thsouth fracture lines as mapped by Issawi (1968) in the area west of Aswan, or along ESE-WNW lines in the Kom Ombo area (Issawi et al., 1978). The drop of about $3000 \mathrm{~m}$ in the level of the Mediterranean Sea during the Messinian dessication (Hsü et al., 1973) accelerated erosional processes along these old structural lines and led to physiographic changes which are still reflected in the area.

During the Messinian a furrow or a trench was formed in the area now occupied by the Nile as far as Aswan or even the second cataract (Chumakov, 1967). Several rivers cut deep gorges through the Palaeozoic-Cretaceous and Eocene clastics and carbonate rocks which once blanketed the area on both sides of the trench. These rivers derived their water from rainfall over the Red Sea hills, Nubia and probably northern Sudan. At the same time the cliffs on both sides of the river channel were lowered and retreated.

The Allaqi River collected much of this water and carried it northwestward to the retreating Barqat Kom Ombo scarp. Wadi Qena was probably opened in the Early Miocene, associated with the Red Sea tectonics. The Qena River then flowed from north to south and gradually built its delta on both sides of the present Nile, establishing its course by the Middle Miocene. The water brought by these rivers from the Eastern Desert wandered along the foot of the scarp west of the present Nile, filling local depressions and perhaps even converging to flow nor thward. 
Thus at the close of the Miocene, there were two main rivers flowing in east Egypt, the Qena River draining most of the northern Eastern Desert and the Allaqi River filtering the waters of most of the remainder of this region. No doubt some of these waters found their way into the old trench which is now occupied by the Nile. Waters then draining the highlands of Ethiopia and equatorial Africa were probably ponded within the Sudd region of Sudan south of Khartoum, or they may have flowed westward through the buried channels recently discovered by McCauley and others (1982) using satellite radar imagery.

By the advent of the Pliocene, the Mediterranean had transgressed deeply into northern Africa, filling most of the existing trenches with marine sediments. The rise of base level led to the aggradation of the rivers far inside their channels, and the formation of Wadi Qena and Wadi Allaqi del tas came to an end.

It is only during the Early to Middle Quaternary, with the regression of the Mediterranean Sea, that rivers started to flow again in this region, reoccupying their old courses and initiating several new ones. Among these were the Kharit, Natash and Shait rivers which deposited the Qena Sands and the Kom Ombo Gravels on the Kom Ombo plain east and west of the present Nile channel. When the Ethiopian waters succeeded in crossing the cataracts in the Nile course, they reached the old Miocene trench. The new active river drained the huge Sudd region and captured the old rivers, rushing northward towards the Mediterranean. These events took place less than 50000 years ago, and a new river system developed in North Africa, attracting people to live on its banks. A new civilization had begun.

\section{References}

Adamson, D.A., 1982. The integrated Nile. In: A Land Between Two Niles: Quaternary Geology and Biology of the Central Sudan. (ed. M.A.J. Williams and D.A. Adamson), A.A. Balkema, Rotterdam, p. 221-234.

Butzer, K.W. and Hansen, C.L., 1968. Desert and river in Nubia: geomorphology and prehistoric environments at the Aswan Reservoir. University of Wisconsin Press. Madison, Wisconsin, 562p.

Caton-Thompson, G. and Gardener, E.W., 1932. The prehistoric geography of Kharga Oasis. Geographical Journal, v. 80 , no. 5 , p. $369-406$.

Chumakov, I.S., 1967. Pliocene and Pleistocene deposits of the Nile Valley in Nubia and Upper Egypt. Transactions Geological Institute, Academy of Sciences of the U.S.S.R., v. 170, 115p, (In Russian).

Hassan, M.Y., Issawi, B. and Zaghloul, E.Z., 1978. Geology of the area east of Beni Suef, Eastern Desert, Egypt. Egyptian Geological Survey Annals, v. 8, p. 129-162.

Haynes, V., Mehringer, P. and Zaghloul, E.A., 1979. Pluvial lakes of North Western Sudan. Geographical Journal, London, v. 145, pt. 3, p. 437-445.

Hsü, K.I., Ryan, W.B.F. and Cita, M.B., 1973. Late Miocene desiccation of the Mediterranean. Nature, v. 242, p. $240-$ 244.

Huzayyin, S.A., 1941. The place of Egypt in Prehistory. Mémoires présentées à l'Institut d'Egypte, v. 43, 440p.

Issawi, B., 1968. The geology of Kurkur-Dungul area. U.A.R. Geological Survey, paper no. 46, 102p.

Issawi, B., 1978. Quaternary geology of Bir Sahara, Western Desert, Egypt. Annals Geological Survey Egypt, v. 8, p. 295-304.

Issawi, B., Hassan, M.Y. and Osman, R., 1978. Geologica! Studies in the area of Kom Ombo, Eastern Desert, Egypt.
Annals Geological Survey Egypt, v. 8, p. 187-235.

Issawi, B. and Hinnawi, M., 1980. Contribution to the geology of the plain west of the Nile between Aswan and Kom Ombo. In: Loaves and Fishes: the Prehistory of Wadi Kubbaniya (assembled by F. Wendorf and R. Schild), Southern Methodist University Press, Appendix 5, p. 311330.

Issawi, B. and Jux, U., 1982. Contributions to the stratigraphy of Paleozoic rocks in Egypt. Egyptian Geological Survey, paper no. 64, 28p.

McCauley, J.F., Schaber, G.G., Breed, C.S., Grolier, M., Haynes, C.V., Issawi, B., Elachi, C. and Blom, R., 1982. Subsurface valleys and geoarchaeology of the eastern Sahara revealed by shuttle radar. Science, v. 218, no. 4576, p. 1004-1020.

Said, R., 1981. The geological evolution of the River Nile, Springer Verlag, New York, N.Y., U.S.A., $151 \mathrm{p}$.

Said, R., Wendorf, F. and Schild, R., 1970. The geology and prehistory of the Nile Valley in Upper Egypt. Archacologia Polona, v. 12, p. 43-60.

Sandford, K.S. and Arkell, W.J., 1939. Paleolithic man and the Nile Valley in Lower Egypt, with some notes upon a part of the Red Sea littoral: a study of the regions during Pliocene and Pleistocene times. Chicago University Oriental Institute Publication no. 46, 105p.

Schild, R. and Wendorf, F., 1977. The prehistory of Dakhla Oasis and the adjacent desert. Wroclaw, Polskiej Akademii Nauk: Ossolineum, 259p.

Schild, R. and Wendorf, F., 1981. The prehistory of an Egyptian oasis. Wroclaw, Polskiej Akademii Nauk: Ossolineum, 155p.

Wendorf, F., 1968. The Prehistory of Nubia, 2 vols. and atlas, Fort Burgwin Research Centre, distributed by Southern Methodist University Press. Dallas. v.I 531p, v.II 1084 p.

Wendorf, F. and Schild, R., 1976. Prehistory of the Nile Valley. New York, Academic Press, 404p.

Wendorf, F. and Schild, R., 1980. Prehistory of the Eastern Sahara. New York, Academic Press, 414p.

Youssef, M.I., 1968. Structural pattern of Egypt and its interpretation. American Association Petroleum Geologists Bulletin. Tulsa, v. 52, no. 4, p. 601-614.

ABOUT THE AUTHOR:

Dr. Bahay Issawi is the Director General of the Egyptian Survey and Mining Authority, (3, Salah Salem St., Abbassiya, Cairo). His principal research interests have been the stratigraphy of the Nubia Sandstone (an important but poorly understood rock unit that is known by one name or another from Morocco to Saudi Arabia) and the geology of the important ironore deposits in and adjacent to the Bahariya Oasis. During his extensive field studies in south Egypt, he discovered the phosphates of the Abu Tartur area near Kharga Oasis and the kaolin deposit at Kalabsha $80 \mathrm{~km}$ southwest of Aswan.

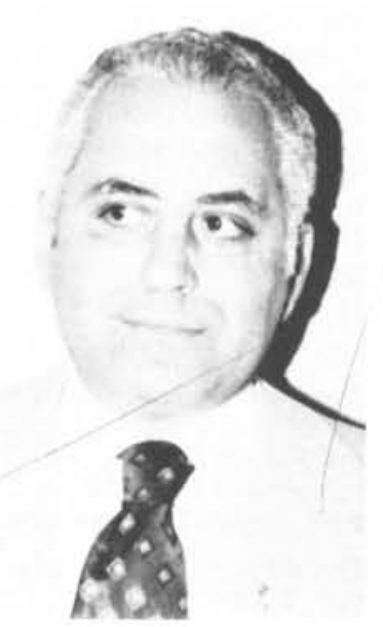

